\title{
Prototype Road Surface Management System
}

\author{
Azad Abdulhafedh \\ University of Missouri, Columbia, MO, USA \\ Email: asa8cd@mail.missouri.edu
}

Received 11 May 2016; accepted 24 May 2016; published 27 May 2016

Copyright (C) 2016 by authors and Scientific Research Publishing Inc.

This work is licensed under the Creative Commons Attribution International License (CC BY). http://creativecommons.org/licenses/by/4.0/

(c) (7) Open Access

\begin{abstract}
The Road Surface Management System (RSMS) is a powerful tool that can provide an overview and rough estimate of a roadway system's condition at the network level and the approximate costs for future improvements in towns and small cities. This helps municipalities and local agencies to apply limited budget resources and provide the greatest road quality benefits. To control the cost of roadway surface deterioration, local agencies and municipalities need to make cost-effective decisions regarding the maintenance, rehabilitation, and reconstruction of the roadway network. RSMS can help in assessing the condition of the network, weighing alternatives, and establishing longterm treatment plans and budgets. In this paper, RSMS is used to evaluate a university campus road network in the state of Idaho and to establish the necessary repair methods for 10 selected sections in the campus network.
\end{abstract}

\section{Keywords}

Road Management System, Cost-Effective Alternatives, Inventory Roads

\section{Introduction}

Pavement preservation and maintenance is a planned system of treating pavements at the optimum time to maximize their useful life, and to enhance pavement longevity at the lowest cost. Pavements perform well under traffic loads until a particular point in their life spans, at which time they deteriorate considerably and rapidly to failure, as shown in Figure 1. Municipalities and local agencies are often challenged with the high cost of maintaining a transportation system, and they must control costs by slowing roadway surface deterioration. This requires making cost effective decisions regarding the maintenance, repair, rehabilitation, and reconstruction of the municipal roadway network. Developing a maintenance budget based on cost-effective decisions requires a rational and systematic process. Typically, communities develop budgets using methods such as last year's budget, worst first, and political pressure. Though these decision-making criteria can work if a community has adequate resources and the majority of road surfaces are in good shape, this is often not the case. As such, municipal officials can benefit from a system that enables them to assess the condition of the network, weigh alternatives, and 
establish long-term programs and budgets. Although road systems are built at considerable cost, many roads show signs of major distress. If these problems are not corrected, the cost to bring the road to an acceptable condition can be many times more expensive than the cost of timely repair. As municipal roads worsen maintenance budgets need to increase. There are more deteriorated streets each year, and the cost per mile for maintenance increases disproportionately. According to the American Association of State Highway and Transportation Officials [1] [2], every $\$ 1$ spent to keep a road in good condition avoids $\$ 6$ - 14 needed later to rebuild the same road once it has deteriorated significantly. The Road Surface Management System (RSMS) is a useful tool to identify a road system's condition and determine the approximate costs for future improvements. RSMS provides a systematic approach for local officials to assess their road system, and to guide future improvement and investment in line with their budget. The RSMS program provides information on the condition, traffic, and importance of roads in a town to create a long term maintenance program. The general road surface management system (RSMS) processing includes the following tasks for the road network [3]:

- Inventory the road system by driving/or walking on the roads and making visual inspections;

- Determine and document the surface distresses condition and drainage condition of each road and entering that data into the program;

- Assign maintenance or repair methods for each condition strategy produced by the program;

- Determine costs of maintenance and repair methods;

- Assign repair and maintenance methods to each road;

- Establish maintenance and repair priorities;

- Establish long-term financial and budget plans.

\section{Methodology}

The University of Idaho (UI) road campus is used to apply the RSMS approach that was developed by the Department of Civil Engineering at the University of New Hampshire. The UI is located in the northern City of Moscow, ID. The methodology used in this paper is implemented using a computer based software package RSMS 11 that addresses the fundamental RSMS tasks, including: identifying the sections and roads in the UI campus network and their importance and the associated traffic volume in a scale of $(1$ - 5) with 1 the lowest and 5 the highest; inventory the road system by making a field survey of the surface distresses and drainage conditions; determining the condition of each road or section, assigning the suitable repair method for each section; determining the cost of each maintenance; rehabilitation or repair method; establishing repair priorities, and planning for long-term budget plans. Further details are shown in the next steps.

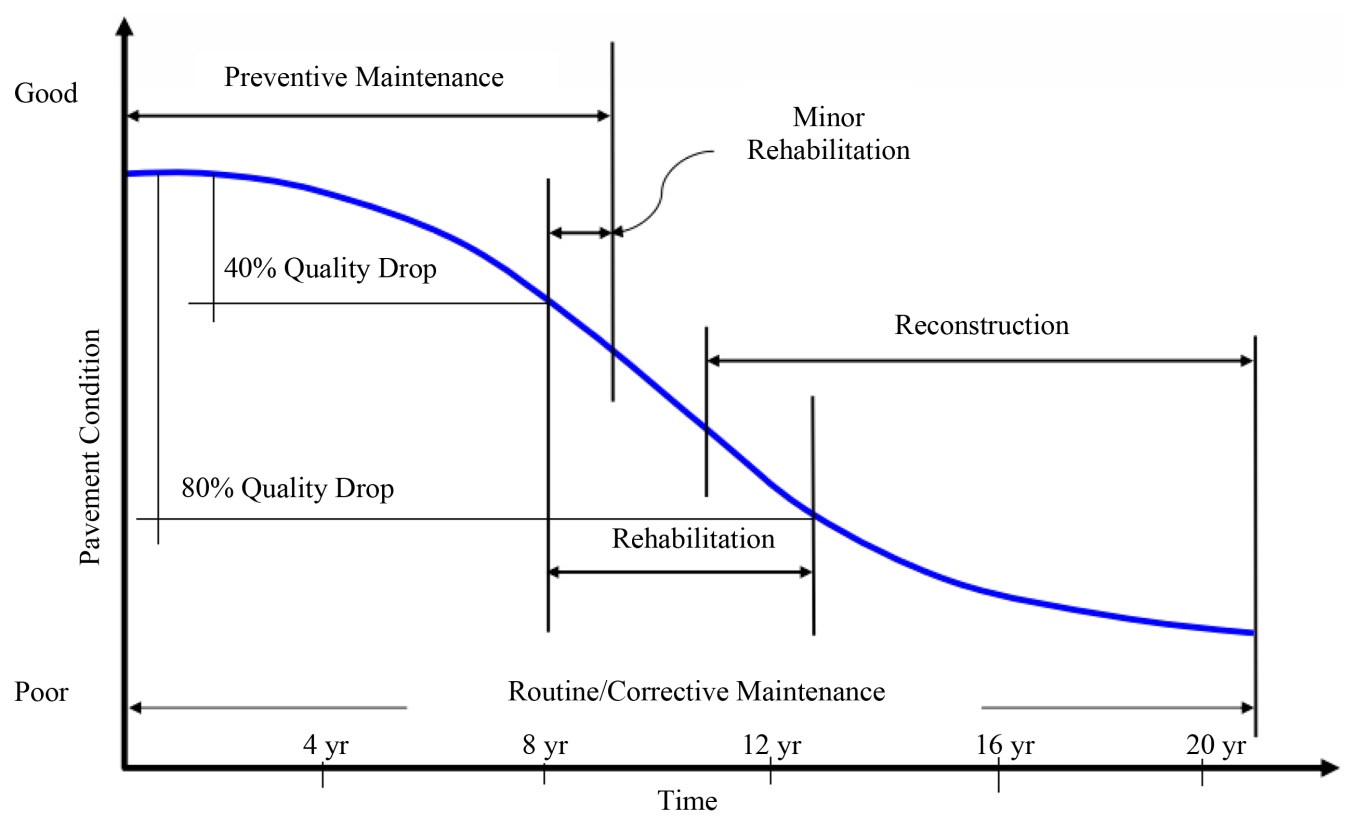

Figure 1. Pavement maintenance, rehabilitation, and construction phases with time. 


\section{Identifying the Deteriorated Road Sections}

The following 10 roads (sections) were selected and identified for evaluation within the UI campus network system (with total length of 5.88 miles):

Section \# 1: $6^{\text {th }}$ Street from Deakin Ave to Perimeter Dr (0.695 miles).

Section \# 2: Perimeter Dr from Blake Ave to SH8 (1.445 miles).

Section \# 3: Stadium Dr from Perimeter Dr to Rayburn Street (0.692 miles).

Section \# 4: Rayburn Street from Perimeter Dr to SH8 (0.592 miles).

Section \# 5: Line Street from University Ave to SH8 (0.445 miles).

Section \# 6: Blake Ave from $6^{\text {th }}$ Street to Taylor Ave (0.502 miles).

Section \# 7: Deakin Ave from $6^{\text {th }}$ Street to Blake Ave (0.486 miles).

Section \# 8: Idaho Ave from Deakin Ave to Stadium Dr (0.436 miles).

Section \# 9: University Ave from Deakin Ave to Line Street (0.329 miles).

Section \# 10: Sweet Ave from UI 95 to Blake Ave (0.341 miles).

An accurate road inventory is a very important part of any pavement management system (PMS) and it is considered the foundation of the system. The required data for the UI campus network were obtained from the campus maps and facility services, and from field survey of each section and road, including its length, width, number of lanes, shoulder type and its width, the importance of the section in a scale of $(1-5)$ with 1 the lowest and 5 the highest, the traffic volume on each section in a scale of $(1-5)$ with 1 the lowest and 5 the highest, the speed limits, right-of-way, and the maintenance division [3]. Table 1 shows the 2016 inventory of the identified paved sections of the UI campus road network in Moscow, ID.

The importance of each section in a scale of $(1-5)$ with 1 the lowest and 5 the highest, and the rank of the existing traffic volume used by each section in a scale of $(1-5)$ with 1 being the lowest and 5 the highest were used in the RSMS as shown in Table 2.

\section{Condition Survey for the Existing Surface Distresses and Drainage Conditions of the Road Sections}

The purpose of the condition survey is to determine the condition of each section by visually observing the surface distresses. The condition survey is crucial to the pavement management system since certain distresses are related to certain causes of pavement deterioration [4] [5]. Due to this direct relationship, RSMS links distress types to the Maintenance, Rehabilitation, and Reconstruction (MR \& R) strategies [3] [6] [7]. Gathering the inventory and road surface condition and drainage condition for each identified section is done by driving on the roads and/or walking on the roads and collecting visual inspections of the existing distresses and the roadside drainage for each road section, recording the SEVERITY and EXTENT of a distress. The severity is ranked as

Table 1. Inventory of the paved sections in the UI campus road network in Moscow, ID.

\begin{tabular}{|c|c|c|c|c|c|c|c|}
\hline $\begin{array}{c}\text { Section } \\
\#\end{array}$ & Name & From & To & $\begin{array}{c}\text { Length } \\
\text { (mile) }\end{array}$ & $\begin{array}{c}\text { Width } \\
\text { (ft) }\end{array}$ & $\begin{array}{c}\text { Number of } \\
\text { Lanes }\end{array}$ & $\begin{array}{l}\text { Shoulder } \\
\text { Width (ft) }\end{array}$ \\
\hline 1 & $6^{\text {th }} \mathrm{St}$ & Deakin Ave & Perimeter Dr & 0.695 & 25 & 2 & 8 \\
\hline 2 & Perimeter Dr & Blake Ave & SH8 & 1.445 & 45 & 4 & 3 \\
\hline 3 & Stadium Dr & Perimeter Dr & Rayburn St & 0.692 & 50 & 4 & 5 \\
\hline 4 & Rayburn St & Perimeter Dr & SH8 & 0.592 & 37.5 & 3 & 6 \\
\hline 5 & Line St & SH8 & University Ave & 0.445 & 32 & 2 & 6 \\
\hline 6 & Blake Ave & $6^{\text {th }} \mathrm{St}$ & Taylor Ave & 0.502 & 37.5 & 3 & 5 \\
\hline 7 & Deakin Ave & $6^{\text {th }} \mathrm{St}$ & Blake Ave & 0.486 & 37.5 & 3 & 6 \\
\hline 8 & Idaho Ave & Deakin Ave & Stadium Dr & 0.436 & 25 & 2 & 3 \\
\hline 9 & University Ave & Deakin Ave & Line St & 0.239 & 25 & 2 & 3 \\
\hline 10 & Sweet Ave & UI 95 & Blake Ave & 0.341 & 37.5 & 3 & 6 \\
\hline
\end{tabular}


(low, medium, and high) depending on the length, width and the visual shape of the existing cracks and distresses, and the extent is ranked as low for $<10 \%$ of the road section area, medium for $10 \%-30 \%$, and high for $>30 \%$ as indicated in the RSMS. Decision trees are used to relate the surface distresses of each section with the appropriate strategy. Each distress type (i.e. alligator cracking, potholes, etc.) has a link that relates each severity/extent condition with an MR \& R strategy. RSMS categorizes each section in term of the strategy repair method and determines its repair options depending on the surface distresses and roadside drainage data input. The type of repair strategies produced by RSMS are the following (No Maintenance, Routine, Preventive, Rehabilitation, and Reconstruction), and each strategy has several repair options. The following types of distresses were inspected and documented by their level of severity and extent:

1) Alligator Cracks

2) Longitudinal/Transverse Cracks

3) Edge Cracking

4) Patches and Potholes

5) Roughness

6) Rutting

7) Roadside Drainage

Table 3 shows the condition survey for each section within the UI campus road network, the different types

Table 2. The importance and traffic volume of the road sections.

\begin{tabular}{ccccc}
\hline Section \# & Name & $\begin{array}{c}\text { Road surface } \\
\text { type }\end{array}$ & $\begin{array}{c}\text { The importance of the section in } \\
(\mathbf{1} \text { - 5) scale }\end{array}$ & $\begin{array}{c}\text { Traffic volume on the section in } \\
\mathbf{( 1} \text { - 5) scale }\end{array}$ \\
\hline 1 & $6^{\text {th }}$ St & Paved & 1 & 1 \\
2 & Perimeter Dr & Paved & 1 & 1 \\
3 & Stadium Dr & Paved & 1 & 1 \\
4 & Rayburn St & Paved & 3 & 3 \\
5 & Line St & Paved & 1 & 1 \\
6 & Blake Ave & Paved & 3 & 3 \\
7 & Deakin Ave & Paved & 2 & 4 \\
8 & Idaho Ave & Paved & 4 & 4 \\
9 & University Ave & Paved & 4 & 1 \\
\hline
\end{tabular}

Table 3. Condition survey of the road sections and RSMS status.

\begin{tabular}{|c|c|c|c|c|c|c|c|c|c|}
\hline $\begin{array}{c}\text { Section } \\
\#\end{array}$ & Name & $\begin{array}{l}\text { Alligator } \\
\text { Cracks }\end{array}$ & $\begin{array}{c}\text { Long/Tran } \\
\text { Cracks }\end{array}$ & $\begin{array}{c}\text { Edge } \\
\text { Cracks }\end{array}$ & $\begin{array}{c}\text { Patches } \\
\text { and } \\
\text { Potholes }\end{array}$ & $\begin{array}{l}\text { Rough- } \\
\text { Ness }\end{array}$ & Rutting & $\begin{array}{c}\text { Road } \\
\text { Drainage }\end{array}$ & $\begin{array}{c}\text { RSMS } \\
\text { Surface } \\
\text { Status }\end{array}$ \\
\hline 1 & $6^{\text {th }} \mathrm{St}$ & Low-med & Low-med & Low-med & Low-low & Low-high & med-low & Low-low & Routine \\
\hline 2 & $\begin{array}{l}\text { Perimeter } \\
\text { Dr }\end{array}$ & Low-med & Low-high & Low-high & Low-low & Med-med & Med-low & Low-low & Preventive \\
\hline 3 & $\begin{array}{l}\text { Stadium } \\
\text { Dr }\end{array}$ & Low-med & Med-med & Med-med & Low-med & Med-med & Med-med & Low-low & Preventive \\
\hline 4 & Rayburn St & Low-med & Low-med & Med-med & Med-low & Med-med & Med-med & Low-low & Preventive \\
\hline 5 & Line St & Low-med & Low-med & Med-med & Low-med & Med-med & Med-low & Low-low & Routine \\
\hline 6 & Blake Ave & Med-med & High-med & High-med & Med-med & High-med & Med-med & Low-low & Rehabilitate \\
\hline 7 & $\begin{array}{l}\text { Deakin } \\
\text { Ave }\end{array}$ & Med-med & Med-med & Med-med & Med-med & High-med & Med-med & Low-low & Rehabilitate \\
\hline 8 & Idaho Ave & Med-med & Med-med & Med-med & Med-med & High-med & Med-med & Low-low & Rehabilitate \\
\hline 9 & $\begin{array}{c}\text { University } \\
\text { Ave }\end{array}$ & Med-med & Med-med & Med-med & Med-low & Med-med & Med-med & Low-low & Rehabilitate \\
\hline 10 & Sweet Ave & Low-low & Low-med & Low-med & Low-low & Med-med & Med-med & Low-low & Preventive \\
\hline
\end{tabular}


of the existing surface distresses and drainage conditions, and the RSMS surface status. Table 4 identifies the sections by the repair strategy of RSMS. Table 5 shows the repair strategy in term of the percent of total network length

\section{Assigning the Suitable Repair Method and Cost-Effective Alternative}

RSMS assigns appropriate repair options for each category [3] whether for maintenance costs depending on the road surface distresses as follows:

- For routine category, RSMS gives the following options (crack seal, and Patching).

- For preventive category, RSMS gives the following options (sand seal, chip seal, thick overlay $>1$ ", thin overlay 3/4" - 1", shim with 1" overlay, 2" cold mix overlay with 1" HMA, and mill and fill 1.25”).

- For rehabilitation category, RSMS gives the following repair options (reclaim incl 6" - 8" base 2" binder 1.5" surface, shim with 2" overlay, reclaim pavement revert to gravel, and RAP reclamation).

Each repair option has an estimated cost and life expectancy that must be the most cost-effective alternative.

Table 6 shows the cost of each repair option for all repair categories, and from this list, the suitable repair option can be selected in the next step.

The selection of the repair option for each section is based on the utilization and optimization of many factors

[6] [8]-[11] such as:

- Repair cost: choose the option with the lowest market price and cost.

- Best technical solution: choose the option that best addresses and cure the current surface distress condition and structural capacity of the section. This is an important weighing factor.

- Life cycle cost: choose the option that allows providing serviceability over the longest possible life cycle of the road.

- User delay cost: choose the option that minimizes the user delay cost of the road and contribute to the public satisfaction.

- Safety and risk minimization: choose the option that increases safety and minimizes the risk to the public.

- Recycling of the materials: choose the option that maximizes the re-use of all materials generated during the rehabilitation process and maximizes the recycling process.

- Environmental effects: choose the option that best fits the environmental/climatic effects surrounding the road.

Comparing the different alternatives of repair options for each section, especially the cost factor and the best

Table 4. RSMS repair strategy of road sections.

\begin{tabular}{|c|c|c|c|c|c|c|c|c|}
\hline \multicolumn{3}{|c|}{ Routine strategy } & \multicolumn{3}{|c|}{ Preventive strategy } & \multicolumn{3}{|c|}{ Rehabilitation strategy } \\
\hline Section \# 1 & $6^{\text {th }}$ street & 0.695 mile & Section \# 2 & Perimeter Dr & 1.445 mile & Section \# 6 & Blake Ave & 0.5 mile \\
\hline \multirow[t]{2}{*}{ Section \# 5} & Line street & 0.445 mile & Section \# 3 & Stadium Dr & 0.692 mile & Section \# 7 & Deakin Ave & 0.49 mile \\
\hline & & & Section \# 4 & Rayburn St & 0.592 mile & Section \# 8 & Idaho Ave & 0.44 mile \\
\hline \multirow{2}{*}{\multicolumn{2}{|c|}{ Total length }} & 1.14 mile & Section \# 10 & Sweet Ave & 0.341 mile & Section \# 9 & University Ave & 0.24 mile \\
\hline & & & \multicolumn{2}{|c|}{ Total length } & 3.07 mile & \multicolumn{2}{|c|}{ Total length } & 1.67 mile \\
\hline
\end{tabular}

Table 5. The repair strategy in term of the percent of total network length.

\begin{tabular}{ccc}
\hline RSMS 11 Repair Strategy & \% of Total Network Length \\
\hline No Maintenance & $0 \%$ \\
Routine Strategy & $20 \%$ \\
Preventive Strategy & $52 \%$ & $28 \%$ \\
Rehabilitation Strategy & $0 \%$ \\
Reconstruction Strategy & \\
\hline
\end{tabular}


Table 6. RSMS estimated cost for the repair options.

\begin{tabular}{|c|c|c|c|}
\hline $\begin{array}{l}\text { Section \# and } \\
\text { Road Name }\end{array}$ & $\begin{array}{l}\text { Repair } \\
\text { Strategy }\end{array}$ & Repair Options & RSMS Estimated Cost in \$ \\
\hline \multirow{2}{*}{$\begin{array}{c}\text { Section \# } 1 \\
6^{\text {th }} \text { street }\end{array}$} & \multirow{2}{*}{ Routine } & Patching & 869 \\
\hline & & Crack seal & 8688 \\
\hline \multirow{7}{*}{$\begin{array}{c}\text { Section \# } 2 \\
\text { Perimeter Dr }\end{array}$} & \multirow{7}{*}{ Preventive } & Sand seal & 52,020 \\
\hline & & Chip seal (latex modified) & 81,281 \\
\hline & & Thin (3/4 - 1 in) overlay & 130,050 \\
\hline & & Shim with 1 in overlay & 211,331 \\
\hline & & Thick ( $>1$ in) overlay & 234,090 \\
\hline & & Overlay w/2 in cold mix, top w/1 in HMA & 380,396 \\
\hline & & Mill and Fill 1.25 in & 406,406 \\
\hline \multirow{7}{*}{$\begin{array}{l}\text { Section \# } 3 \\
\text { Stadium Dr }\end{array}$} & \multirow{7}{*}{ Preventive } & Sand seal & 27,680 \\
\hline & & Chip seal (latex modified) & 43,250 \\
\hline & & Thin (3/4 - 1 in) overlay & 69,200 \\
\hline & & Shim with 1 in overlay & 112,450 \\
\hline & & Thick (>1 in) overlay & 124,560 \\
\hline & & Overlay w/2 in cold mix, top w/1 in HMA & 202,410 \\
\hline & & Mill and Fill 1.25 in & 216,250 \\
\hline \multirow{7}{*}{$\begin{array}{c}\text { Section \# } 4 \\
\text { Rayburn street }\end{array}$} & \multirow{7}{*}{ Preventive } & Sand seal & 17,997 \\
\hline & & Chip seal (latex modified) & 28,120 \\
\hline & & Thin (3/4 - 1 in) overlay & 44,992 \\
\hline & & Shim with 1 in overlay & 73,112 \\
\hline & & Thick (>1 in) overlay & 80,986 \\
\hline & & Overlay w/2 in cold mix, top w/1 in HMA & 131,602 \\
\hline & & Mill and Fill 1.25 in & 140,600 \\
\hline \multirow{2}{*}{$\begin{array}{l}\text { Section \# } 5 \\
\text { Line street }\end{array}$} & \multirow{2}{*}{ Routine } & Patching & 712 \\
\hline & & Crack seal & 7120 \\
\hline \multirow{5}{*}{$\begin{array}{l}\text { Section \# } 6 \\
\text { Blake Ave }\end{array}$} & \multirow{5}{*}{ Rehabilitate } & Reclaim pavement, revert to gravel & 19,076 \\
\hline & & Shim with 2 in overlay & 123,994 \\
\hline & & Reclaim incl 6 - 8 in base, 2 in binder, 1.5 in surface & 190,760 \\
\hline & & Reclaim incl 6 - 8 in base, stabilized, 2 in binder, 1.5 in surface & 233,681 \\
\hline & & PM RAP reclamation & 233,681 \\
\hline \multirow{5}{*}{$\begin{array}{l}\text { Section \# } 7 \\
\text { Deakin Ave }\end{array}$} & \multirow{5}{*}{ Rehabilitate } & Reclaim pavement, revert to gravel & 18,468 \\
\hline & & Shim with 2 in overlay & 120,042 \\
\hline & & Reclaim incl 6 - 8 in base, 2 in binder, 1.5 in surface & 184,680 \\
\hline & & Reclaim incl 6 - 8 in base, stabilized, 2 in binder, 1.5 in surface & 226,233 \\
\hline & & PM RAP reclamation & 226,233 \\
\hline \multirow{5}{*}{$\begin{array}{l}\text { Section \# } 8 \\
\text { Idaho Ave }\end{array}$} & \multirow{5}{*}{ Rehabilitate } & Reclaim pavement, revert to gravel & 10,900 \\
\hline & & Shim with 2 in overlay & 70,850 \\
\hline & & Reclaim incl 6 - 8 in base, 2 in binder, 1.5 in surface & 109,000 \\
\hline & & Reclaim incl 6 - 8 in base, stabilized, 2 in binder, 1.5 in surface & 133,525 \\
\hline & & PM RAP reclamation & 133,525 \\
\hline
\end{tabular}




\begin{tabular}{|c|c|c|c|}
\hline \multicolumn{4}{|l|}{ Continued } \\
\hline \multirow{5}{*}{$\begin{array}{c}\text { Section \# } 9 \\
\text { University Ave }\end{array}$} & \multirow{5}{*}{ Rehabilitate } & Reclaim pavement, revert to gravel & 5975 \\
\hline & & Shim with 2 in overlay & 38,838 \\
\hline & & Reclaim incl 6 - 8 in base, 2 in binder, 1.5 in surface & 59,750 \\
\hline & & Reclaim incl 6 - 8 in base, stabilized, 2 in binder, 1.5 in surface & 73,194 \\
\hline & & PM RAP reclamation & 73,194 \\
\hline \multirow{7}{*}{$\begin{array}{l}\text { Section \# } 10 \\
\text { Sweet Ave }\end{array}$} & \multirow{7}{*}{ Preventive } & Sand seal & 10,366 \\
\hline & & Chip seal (latex modified) & 16,198 \\
\hline & & Thin (3/4 - 1 in) overlay & 25,916 \\
\hline & & Shim with 1 in overlay & 42,114 \\
\hline & & Thick ( $>1$ in) overlay & 46,649 \\
\hline & & Overlay w/2 in cold mix, top w/1 in HMA & 75,804 \\
\hline & & Mill and Fill 1.25 in & 80,988 \\
\hline
\end{tabular}

technical solution suitable for each section, and weighing the factors above, the appropriate repair methods and budgets were selected with reasoning of the selection as shown in Table 7.

\section{Determining the Cost of Each Repair Method}

RSMS uses an estimate of the prices and costs of the different repair methods based on 1 mile road length and $20 \mathrm{ft}$ wide road as shown in Table 8 . The total cost of each section can be determined based on the actual length and width of the section.

The RSMS costs shown above can be modified by each agency to reflect the most recent market prices within its jurisdiction.

\section{Establishing Repair Priorities}

Repair strategies must be analyzed based on their technical and economical impacts so that priority program at the network level can be identified and later implemented at the project level. RSMS prioritizes the repair of all sections based on the surface distresses and the drainage conditions. RSMS gives the highest priority value to road sections that need routine maintenance and having poor drainage, and gives the lowest priority value to road sections that have good drainage but need major rehabilitation. In the UI Campus network, the priority was given to the sections that need routine maintenance in the financial plan because it costs less than other strategies and to effectively extent the life cycle of these low cost sections. Table 9 shows the repair priority of the sections depending on the repair strategy.

\section{Long-Term Financial and Budget Plans}

Long-term financial and budget plans are necessary planning tools for any PMS because it can allocate the required resources and budgets per each year in the future planned period. RSMS can prepare long-term financial and budget plans for up to 15 years if the required data were available and entered into the program regarding the repair costs of each section within any number of future years up to 15. Table 10 shows the financial budget plan for the UI network repair from 2016 to 2024 using the estimated costs of repair of the RSMS, depending on the estimated repair methods used by the program.

\section{Conclusion}

The Road Surface Management System (RSMS) is a data-intensive program that uses three categories of data; road network inventory, road surface condition survey, and maintenance, rehabilitation and reconstruction (MR \& R) strategies and associated unit costs and life expectancy. RSMS is a powerful tool to assist town managers, road commissioners, public works directors, road committees, and budget committees develop a maintenance 
Table 7. Choosing the budget.

\begin{tabular}{|c|c|c|c|c|c|}
\hline $\begin{array}{c}\text { Section } \\
\quad \#\end{array}$ & Name & $\begin{array}{c}\text { RSMS Repair } \\
\text { Strategy }\end{array}$ & $\begin{array}{c}\text { Chosen Repair } \\
\text { Option }\end{array}$ & $\begin{array}{c}\text { RSMS } \\
\text { Budget (\$) }\end{array}$ & Reason for Selection \\
\hline 1 & $6^{\text {th }} \mathrm{St}$ & Routine & Crack seal & 8688 & $\begin{array}{l}\text {-cost effective } \\
\text {-addresses the current long/tran cracks in the section } \\
\text {-fits the overall good road surface condition } \\
\text {-good typical life cycle performance } 3 \text { - } 5 \text { years }\end{array}$ \\
\hline 2 & $\begin{array}{l}\text { Perimeter } \\
\text { Dr }\end{array}$ & Preventive & $\begin{array}{l}\text { Chip seal (Latex } \\
\text { modified) }\end{array}$ & 81,281 & $\begin{array}{l}\text {-can waterproof the surface } \\
\text {-can restore surface friction } \\
\text {-relatively more cost effective than an overlay } \\
\text {-provide sealing to low severity cracks } \\
\text {-good typical performance life } 4 \text { - } 7 \text { years } \\
\text {-provide opportunity to apply multiple treatments }\end{array}$ \\
\hline 3 & Stadium Dr & Preventive & $\begin{array}{l}\text { Chip seal (Latex } \\
\text { modified) }\end{array}$ & 43,250 & $\begin{array}{l}\text {-can waterproof the surface } \\
\text {-can restore surface friction } \\
\text {-relatively more cost effective than an overlay } \\
\text {-provide sealing to low severity cracks } \\
\text {-good typical performance life } 4 \text { - } 7 \text { years } \\
\text {-provide opportunity to apply multiple treatments }\end{array}$ \\
\hline 4 & Rayburn St & Preventive & $\begin{array}{l}\text { Chip seal (Latex } \\
\text { modified) }\end{array}$ & 28,120 & $\begin{array}{l}\text {-can waterproof the surface } \\
\text {-can restore surface friction } \\
\text {-relatively more cost effective than an overlay } \\
\text {-provide sealing to low severity cracks } \\
\text {-good typical performance life } 4 \text { - } 7 \text { years } \\
\text {-provide opportunity to apply multiple treatments }\end{array}$ \\
\hline 5 & Line St & Routine & Crack seal & 9790 & $\begin{array}{l}\text {-cost effective } \\
\text {-addresses the current long/tran cracks in the section } \\
\text {-fits the overall good road surface condition } \\
\text {-good typical life cycle performance } 3 \text { - } 5 \text { years }\end{array}$ \\
\hline 6 & Blake Ave & Rehabilitate & $\begin{array}{c}\text { Shim w/2” } \\
\text { overlay }\end{array}$ & 122,363 & $\begin{array}{l}\text {-improves road profile, crown, and slopes } \\
\text {-corrects rutting and other surface distresses } \\
\text {-reworks the AC to depth of } 2 \text { in } \\
\text {-Typical performance } 5 \text { - } 10 \text { years } \\
\text {-more cost effective than mill and fill 1.25” or } \\
\text { overlay w/cold mix 2” and hot mix top 1” }\end{array}$ \\
\hline 7 & Deakin Ave & Rehabilitate & $\begin{array}{c}\text { Shim w/2” } \\
\text { overlay }\end{array}$ & 140,400 & $\begin{array}{l}\text {-improves road profile, crown, and slopes } \\
\text {-corrects rutting and other surface distresses } \\
\text {-reworks the AC to depth of } 2 \text { in } \\
\text {-Typical performance } 5 \text { - } 10 \text { years } \\
\text {-more cost effective than mill and fill } 1.25 \text { ” or } \\
\text { overlay w/cold mix 2” and hot mix top 1” }\end{array}$ \\
\hline 8 & Idaho Ave & Rehabilitate & $\begin{array}{c}\text { Shim w/2” } \\
\text { overlay }\end{array}$ & 70,850 & $\begin{array}{l}\text {-improves road profile, crown, and slopes } \\
\text {-corrects rutting and other surface distresses } \\
\text {-reworks the AC to depth of } 2 \text { in } \\
\text {-Typical performance } 5 \text { - } 10 \text { years } \\
\text {-more cost effective than other rehab methods like } \\
\text { mill and fill } 1.25 \text { ” or overlay w/cold mix } 2 \text { " and hot } \\
\text { mix top 1” }\end{array}$ \\
\hline 9 & $\begin{array}{c}\text { University } \\
\text { Ave }\end{array}$ & Rehabilitate & $\begin{array}{c}\text { Shim w/2” } \\
\text { overlay }\end{array}$ & 38,838 & $\begin{array}{l}\text {-improves road profile, crown, and slopes } \\
\text {-corrects rutting and other surface distresses } \\
\text {-reworks the AC to depth of } 2 \text { in } \\
\text {-Typical performance } 5 \text { - } 10 \text { years } \\
\text {-more cost effective than other rehab methods like } \\
\text { mill and fill } 1.25 \text { ” or overlay w/cold mix 2" and hot } \\
\text { mix top 1" }\end{array}$ \\
\hline 10 & Sweet Ave & Preventive & Chip seal & 16,198 & $\begin{array}{l}\text {-can waterproof the surface } \\
\text {-can restore surface friction } \\
\text {-relatively more cost effective than an overlay } \\
\text {-provide sealing to low severity cracks } \\
\text {-good typical performance life } 4 \text { - } 7 \text { years } \\
\text {-provide opportunity to apply multiple treatments }\end{array}$ \\
\hline \multicolumn{6}{|c|}{ Total \$ 559,778 } \\
\hline
\end{tabular}


Table 8. The RSMS cost of 1 mile road length and $20 \mathrm{ft}$ wide road.

\begin{tabular}{cc}
\hline Repair Description & Cost \$/mile \\
Crack seal & 10,000 \\
Patching & 1000 \\
Sans seal & 16,000 \\
Chip seal & 25,000 \\
Thick overlay >1” & 72,000 \\
Thin overlay 3/4” - 1” & 40,000 \\
Shim with 1” overlay & 65,000 \\
2" Cold mix overlay with 1” top HMA & 117,000 \\
Mill and fill 1.25” & 125,000 \\
Reclaim incl 6” - 8” base 2” binder 1.5” surface & 200,000 \\
Reclaim incl 6” - 8” base 2”, stabilized, binder 1.5” surface & 245,000 \\
Shim with 2” overlay & 130,000 \\
Reclaim pavement revert to gravel & 20,000 \\
PM RAP reclamation & 245,000 \\
18” New 9.5 mm gravel, 2” binder, 1” surface & 225,000 \\
24” New gravel, 2" binder, 2” surface & 300,000
\end{tabular}

Table 9. RSMS repair priority.

\begin{tabular}{cccc}
\hline Section \# & Road Name & RSMS Surface Condition & Repair Priority \\
\hline 1 & 6 th St & Routine & 1 \\
5 & Line St & Routine & 2 \\
4 & Rayburn St & Preventive & 3 \\
2 & Perimeter Dr & Preventive & 4 \\
3 & Stadium Dr & Preventive & 5 \\
10 & Sweet Ave & Preventive & 6 \\
8 & Idaho Ave & Rehabilitate & 7 \\
9 & University Ave & Rehabilitate & 8 \\
7 & Blake Ave & Rehabilitate & 9 \\
\hline
\end{tabular}

Table 10. RSMS long term budget plan.

\begin{tabular}{cccccccccc}
\hline Year & $\mathbf{2 0 1 6}$ & $\mathbf{2 0 1 7}$ & $\mathbf{2 0 1 8}$ & $\mathbf{2 0 1 9}$ & $\mathbf{2 0 2 0}$ & $\mathbf{2 0 2 1}$ & $\mathbf{2 0 2 2}$ & $\mathbf{2 0 2 3}$ & $\mathbf{2 0 2 4}$ \\
\hline Planned long-term Budget in \$ & 559,778 & 280,273 & 334,800 & 340,331 & 496,072 & 481,850 & 382,891 & 507,691 & 310,994 \\
\hline
\end{tabular}

plan for their paved road network. RSMS is intended to provide an estimate of a roadway network level condition for towns and small cities and the approximate costs for their repair methods and future improvements. The University of Idaho campus road network is evaluated using the RSMS process. Inventory conditions are conducted by driving and/or walking on 10 sections that are identified within the UI campus (with total length of 5.88 mile) and their inventory conditions are used. RSMS classifies $20 \%$ of the total network length as in need of "Routine repair", 52\% of the total network length as in need of "Preventive repair", and $28 \%$ as in need of "Rehabilitation repair". The adequate repair option is selected for each section through the optimization of the cost effective factors and the most suitable technical solutions with the associated budget, and the program prioritizes the repair of the roads beginning with the routine strategy, then the preventive, and then the rehabilitation strategies. Appropriate budget plans are established by the program for the long-term work as well. 


\section{References}

[1] AASHTO (2011) A Policy on Geometric Design of Highways and Streets. The American Association of State Highway and Transportation Officials, AASHTO Green Book, Washington DC.

[2] NCPP (2016) Retrieved May 17, 2016 from the National Center for Pavement Preservation. www.pavementpreservation.org

[3] RSMS (2016) RSMS User Group. http://www.rsms.info/

[4] Peshkin, S., Krstulovich, W. and Alvarado, M. (2011) Guidelines for the Preservation of High-Traffic Volume Roads: SHRP 2 Renewal Research, Report S2-R26-RR-2.

[5] AASHTO (2008) Transportation System Preservation Research, Development, and Implementation Roadmap. The American Association of State Highway and Transportation Officials, Washington DC.

[6] Haas, R., Hudson, W. and Zaniewski, J. (1994) Modern Pavement Management. Krieger Publishing Company, Malabar.

[7] Peshkin, S. and Hoerner, M. (2005) Pavement Preservation: Practices, Research Plans, and Initiatives: NCHRP 20-07, Task 184.

[8] Mubaraki, M. (2014) Proposed Integrated Road Surface Management System for Small Municipalities. Proceedings of the Institution of Civil Engineers, Municipal Engineer, 166, 239-249. http://dx.doi.org/10.1680/muen.12.00047

[9] Bendtsen, H. and Schmidt, B. (2006) Integrating Noise in Pavement Management Systems for Urban Roads. NORDIC Road and Transport Research Publication, 3, 26-27.

[10] Descornet, G. (1989) A Criterion for Optimizing Surface Characteristics. Transportation Research Record, 1215, 173177.

[11] Tighe, L., Li, N., Falls, L.C. and Haas, R. (2000) Incorporating Road Safety into Pavement Management. Transportation Research Record, 1699, 1-10. http://dx.doi.org/10.3141/1699-01 